\title{
Tears of the Collective: Healing Historical Trauma through Community Arts
}

\author{
Te Oti Rakena \\ University of Auckland, New Zealand
}

In this paper, I advocate that culture matters in music education and should be a measure we consider when we assess the quality of music-making in the community. Community arts education can address a multitude of social issues that impact marginalized communities if viewed through an appropriate lens. I propose historical trauma as an appropriate lens for a (post)colonial context. It provides a framework for disrupting music education practices in university music programs and reconsidering the competencies that need to be emphasized when training conservatory educated performers to be community music facilitators. This text is a story, written in the style of a genealogical narrative (whakapapa körero). It moves through a specific body of experiences, interconnected stories, contexts and emotions, a process identified by indigenous social work researchers as a culturally appropriate healing intervention for indigenous communities. If you are looking for a bullet-pointed exposition of suitable procedures to employ in your work, you are missing the point. In the past we indigenous academics have made it very easy for other academics and researchers to access our knowledge, but to appreciate the new knowing offered in this text you will have to work a little harder. You will need to shift your cultural paradigm and any academic bias to a world where you are not given direct answers, but rather you are encouraged to listen (and with the audio examples provided I mean that literally), reflect, become aware of your physical reactions, open yourself to the spiritual dimension and consider how these words and sounds may impact your future thinking. Most importantly, I hope this chapter will allow you to understand and share the un-mourned grief of the indigenous people in your (s)p(l)ace.

Keywords: Indigenous, community music, historical trauma, Māori, Pacific Island, community arts education.

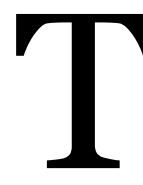

he genesis of this text was a keynote conversation with Brydie Leigh Bartleet at the 2017 World Alliance of Arts Education conference located on the University of Auckland marae Waipapa, a key note address transformed by indigenous ritual, refreshed by non-western perspectives and provocations around colonial legacies and historical trauma. The second outing of this topic was as a Pecha Kucha presentation at the 33rd World Conference of the International Society for Music Education Community Music 
Activities Research Commission in the city of Tbilisi in the Republic of Georgia. The third iteration was in a live performance mode with indigenous student collaborators from my School of Music. This version blends all the former iterations together and builds on the results of those experiences and feedback. Part narrative, part lyric essay, part report, part reflection, the shape of the text is designed to capture the ambience of all those moments. This work is supported by two recordings. The first is the author singing a Mōteatea (a type of Māori song) written by Hone Hurihanganui for the Bone Feeder. The Opera, with libretto by Rene Liang and music by Gareth Farr, was a multilingual work in Māori, Cantonese and English that provided a performative framework for speaking about past trauma. A second recording offers another opportunity to link sound to text. This example backgrounds the musical object and foregrounds the voices of a community responding to a disruption in the performance conventions associated with the musical object. It is an act of resilience and resistance initiated by a new generation of indigenous performer, an entertainer/activist addressing the impact of historical trauma on their community by transforming the public narrative associated with the artistic object.

\section{Tauparapara ${ }^{1}$}

[Audio Link]

The event: Keynote address at the 2017 World Alliance for Arts Education

The date: 21 November, 2017

The location: Auckland, Aotearoa/New Zealand, the South Pacific

We sit quietly in the meeting house (whare nui) of the host university. Our young people sing and dance (haka pōwhiri), welcoming distinguished visitors from many distant lands. Our women call them into the space (karanga); the sound is powerful and spiritual, a sound that has echoed through the generations and across the Pacific. We sit solemnly as the guests find their way into the unfamiliar building. They sit expectedly, unsure of the process, unsure of what is to come. Some are clearly uncomfortable, some excited. Many eyes explore the highly ornamented building. The ceiling design, the carved posts, the patterned panels-all are beautifully crafted. It is exotic but not performative. We are all participants in this moment; no one is audience.

Te Oti Rakena, Te Oti. 2019. Tears of the collective: Healing historical trauma through community arts. Action, Criticism, and Theory for Music Education 18 (2): 130-46. http://dx. doi.org/10.22176/act18.2.130 
At home-by this I mean in my tribal area-we refer to this building as an ancestral house (whare tupuna). It symbolizes the body of an important tribal ancestor. It is less a building and more a living, spiritual being. Our relationship with the house is familial. If we can recite a lineage to this ancestor (whakapapa), we can call it home. We greet this ancestor and so do visitors. We touch it, we place our nose against it and share the breath of life (hongi), we ask its advice, we debate within it, and we celebrate within it. We bring our loved ones home to rest here before their spirits (wairua) return to our ancestral homeland (Hawaiki). This ancestor has many stories. This ancestor has witnessed our joy, our pain, our trials and our tribulations. The ancestor's ribs and spine are ornamented with our people's stories, an embodiment of our history.

In this meeting house we greet Tänenuiarangi, ${ }^{2}$ the ancestor symbolically represented by the master carver 3 of this meeting house. The stories of the canoes that brought the ancestors of Māori4 to Aoteaora5/New Zealand ornament his body. Tangi'ia, ${ }^{6}$ an ancestor who connects the major islands of the South Pacific with New Zealand, is also represented. And so this house, intended for an urban educational setting, is an ancestor-god that all the children of the South Pacific can identify with.

Today, Tānenuiarangi welcomes these children and a global collective of arts educators. He watches over the gathering, ensuring all the protocols (tīkanga) are carried out appropriately, and that Māori traditions are respected. He makes sure the guests are shown respect, generosity and hospitality (manaaki).

Haere mai ki te whenua o Aotearoa (Welcome to the land of Aotearoa/New Zealand)

Haere mai ki te ao Māori (Welcome to the world of the Māori)

\section{The conversation begins...}

The importance of this moment may be lost on some guests, but for those of us who are searching for the post in (post)colonialism, or still trying to access the traditions of the cultures of power, this is an unusual and significant moment. This will not be the last time delegates meet an unfamiliar scenario. This conference has unfamiliar and unconventional moments sprinkled throughout. I will call them disruptions. Those of us fortunate enough to participate in the "conference circuit" have become very comfortable with the conference 
traditions of the academy, an institution whose education traditions have sculpted our research practices. But, welcome to Aotearoa/New Zealand, and in particular this conference, where you will encounter many disruptions. I would like to unpack a few of those moments.

The first disruption was a Māori ritual known as a pōwhiri. Its purpose: to welcome you to our conference space. We acknowledged the local tribe (iwi), your ancestors, our ancestors, the physical space in which we meet, and the spirits of those gone before us. You responded by demonstrating that you are here as friends not enemies. You acknowledged our space, our ancestors, shared the breath of life with us, ate our food and welcomed our hospitality.

Now you are in the first keynote presentation of this conference, but it is not a keynote address. It is another disruption, it is a keynote conversation. Two speakers share their knowledge and experiences about their community practices. They converse with, and for, the conference delegates.

I am another disruption.

Who am I? Why am I first?

My colleagues are well known in their respective areas-more famous, more celebrated. Some might say they should have presented in this prime slot. In a conference with the theme Engaging with Communities, this disruption is perhaps the most significant. It signals the conference team's commitment to a document called the Treaty of Waitangi, a historic text signed by some Māori leaders and representatives of the British Crown. It was designed to create a partnership with these peoples and ensure the Crown would "protect Māori culture and enable Māori to live in New Zealand as Māori” (Ministry of Justice n.d.). The team recognizes that they are treaty partners and that a story about New Zealand is not just the European settler story or some other colonial narrative. It is a South Pacific tale. The conference team chose to put an indigenous perspective front and center, acknowledging the nation's long, rich history prior to colonial settlement. It is an attempt to address what Duran and Duran (1995) call the "soul wound" (24), the collective intergenerational wounding that many indigenous communities, including my people, have suffered through our experiences of colonialism. In settler colonies such as this, and all nations where the colonizing forces have not left (and with whom we share our land), these traumas are continuously reinforced by the dominant culture-a culture of power that creates its own account of indigenous history, and its own "artificial images" of its marginalized communities (Sheffield 2011, 95).

Te Oti Rakena, Te Oti. 2019. Tears of the collective: Healing historical trauma through community arts. Action, Criticism, and Theory for Music Education 18 (2): 130-46. http://dx. doi.org/10.22176/act18.2.130 
I am a disruption because I am indigenous. I represent my collective, an indigenous community that within a global context only recently experienced colonial occupation. Nonetheless, we have many complex and rich stories to share. Like many other indigenous communities, we are well-researched, often as an object, less often as a subject. The social-political reality of my community (Smith 1999) and the way they have experienced colonial occupation shapes the way I teach music, prepare future community music facilitators, design curriculum and explore the music practices of other communities. By pausing to consider how this work may impact the people (he tangata, he tangata, he tangata $^{7}$ ), I disrupt the flow of research and pedagogical processes. By imagining the filter through which these people view the world I have a strategy that allows me to design more relevant curriculum and build stronger linkages with community groups. A respectful acknowledgement of the socio-political dimensions of a community's reality has become an active ingredient (DeNora 2016) in my educator's tool box and with respect to the aforementioned Treaty of Waitangi, allows me to partnership more effectively. If we take the time to understand a community's version of their history, appreciate the way it has impacted their ancestors and observe how this has manifested over the generations, pedagogues can forge more meaningful relationships and create more credible educational sites.

\section{A brief disruption to the keynote conversation}

A few years ago, I attended Brown University's International Advanced Research Institute (BIARI). I was attached to a research cluster that was looking at Development and Inequality in the Global South. All the participants were either from developing nations or had an interest in the subaltern or indigenous. A performance artist from this institute was asked to provide a piece of live performance art for a gala held in a gallery at the Rhode Island School of Design. The artist asked indigenous and minority participants from colonised countries to participate. He deliberately targeted lands historically exploited by colonial forces for the economic well-being of their nation states. In the gallery invited guests and dignitaries sipped champagne, nibbled hors d'eouvres, chatted and admired the beautiful objects, noble portraits, sculptures and other lavish representations of Europe's past wealth and power. The artist created a runway down the middle of the gallery and we entered as if it were a red-carpet 
event. We walked down the runaway and reacted to the paintings on the walls. Unlike a group of tourists or art aficionados we did not celebrate the beautiful works of art. We cried, we grieved, we screamed, we looked with horror at these public representations of colonial history and we filled the space with a soundscape rarely heard in a temple of western art. It was a collective expression of "disenfranchised grief" (Brave Heart 1999, 60) that had travelled across the generations and around the globe. We created a different type of community music.

This was a powerful moment for someone like me who has devoted their lives to the celebration of Western European art music. In this context the art objects acted as public reminders of historical trauma, promoting the narrative of the culture of power and in a Foucauldian way diminishing the value of the subaltern's counter narrative (Foucault 1984). Nowadays, in less patroned times, creative artists often use their work and celebrity in socially responsive ways. Actors' images have been captured supporting indigenous rights at the Standing Rock Reservation pipeline protest, comedians and celebrities created the charity Comic Relief to end poverty and visual artists and cultural workers have connected to support the Artists for Palestine UK pledge for freedom, justice and equality. These global citizens have social media tools at their disposal and can zoom out if you will and observe the impact of nationhood in a more global context. Contemporary creative artists seem more mindful of the people cost of their art-making, more aware of the positive impact their works may have on communities in strife and more attentive to the power their social influencer status has on the dissemination of information about acts of injustice. In other words, if creative artists of the past had been globalized rather than imperialized, perhaps they would have provided historical records of their nations' genocides, massacres, forced removal from ancestral lands, residential schools, sexual abuse, rape, cultural suppression, slavery, forced conversions, introduction of disease.

\section{The conversation continues...}

This brings me to the notion of historical trauma a concept that first emerged in the literature of behavioral and health sciences in the 1990s. In recent years, the term has become "a popular trope to describe the long-term impact of colonization, cultural suppression and the historical oppression of many 
indigenous peoples" (Kirmayer, Gone and Moses 2014, 300). It has been used to link the health disparities of indigenous communities to traumatic events that occurred through the process of colonization. These are social issues some indigenous academics relate to unresolved grief arising from generations of unacknowledged trauma (Brave Heart 1999; Pihama et al. 2014; Wirihana and Smith 2014). However, some academics have found the concept problematic as a theoretical framework as it relies on past causal factors for influencing present day experiences. They critique these theories by acknowledging that we cannot precisely document what happened in the past, our knowledge of the past is contained in narrative (Young 1997; Meštrović 1985). They see trauma as a process independent of the causal event and therefore a representation of that event. Their work problematizes studies that link past traumatic events to present day outcomes by reminding us that collective memory is highly malleable and a reconstructive process therefore highly contestable (Meštrović 1985, 129). And so, historical trauma has been challenging to quantify in academic terms, but as a concept, it manages to capture an important part of the indigenous experience that other models do not (Evans-Campbell 2008, 317).

Considering the way historical trauma is represented in contemporary community stories offers a solution to the problem of projecting contemporary theory back in time. Contemporary community stories are public narratives that string together events to construct meaning and establish discourse (Milner 2012). Researchers extend the definition of public narrative to include images, social media, ideas and music all considered raw materials in the construction of societal discourse (Mohatt et al. 2014; Milner 2012; Hinyard and Kreuter 2007; Riessman 1993). This evolution of the parameters of the public narrative can be related to Dawkins' term meme, which he described as an element of a culture that may be passed from one individual to another by nongenetic means (1976). A meme is a unit of cultural transmission, which evolves as a gene, and undergoes natural selection in the Darwinian sense (Atran 2001). Atran extended the meaning of meme beyond that of public narrative to include word, sentence, thought, belief, dance and many other cultural expressions and community art practices. How has the public narrative through memes, been remixed, recirculated, mutated and evolved by the community and by the culture of power? This is a part of what has constructed a community's identity and can diverge from the academic bubble of mainstream thought and the teaching of peoples' histories. It can be difficult to move beyond these past 
traumas when public representations in contemporary contexts act as reminders of past losses.

In Aotearoa/New Zealand we see daily examples of Māori communities, Pacific Island minorities, and increasingly our refugee communities creating and maintaining wellness after trauma. Community-based arts play a significant role in this healing, providing a creative (s)p(l)ace (de Cosson 2004) where people can collectively strengthen cultural identity and transform public narratives to promote resiliency (Mohatt et al. 2014, 130). While these is no one unified Māori perspective (Panelli and Tipa 2007) one of the healing interventions uses genealogical narratives (whakapapa kōrero), a body of knowledge that interconnects with the performing arts, such as song, chant, lament, formal speech and dance, to create therapeutic methods for expressing emotions (Wirihana and Smith 2014, 202). Whakapapa Kōrero can be historic or contemporary narratives about the relationships of communities with their environment and other peoples. The mōteatea linked to this text is an example of this.

The indigenous Māori performing genre Kapa Haka is another example of the genealogical narrative being used in a therapeutic way, a physicalizing of emotion in the performance space (Wirihana and Smith 2014, 202). As a community music, Kapa Haka for much of its history "was an artistic creation with a Eurocentric aesthetic that romanticized the happy Polynesian singing on his South Pacific Island" (Rakena 2016a, 123). Smith (2003) notes that this has led to multiple ways of knowing Kapa Haka, the colonial and the Māori, but we can also interpret this as a community meme with its roots in the created traditions propagated by a colonial cultural heritage process and transformed by the indigenous community into a contemporary site of resistance. The genre has become the focus of the community's revitalization of the language, relearning of traditional music practices and an important decolonized space for artistic creation and political commentary (Rakena 2016a). The community's ownership and transformation of public narrative expressed through these types of art practices is a key element to resolving past acts of injustice (Wirihana and Smith 2014).

This type of indigenous activity aligns with community music's historical roots in the community arts movement and supports its traditionally postmodern position advocating for "people, process, community, participation and informal/non-formal education" (Higgins 2012). However, part of community music's "genealogical narrative" is that it arose in the 1960's in resistance to 
"high art" (Higgins 2012, 40). This makes my day job in a conservatory-based School of Music a little awkward.

\section{Confessions of an opera singer, a penitent disrupts}

I would like to take a moment to fully disclose the teams I play on. I am professionally a teacher of classical voice in the largest University in New Zealand, and the Head of Vocal Studies. This is the first time an indigenous person has held this position in my country. I trained as an Opera singer in a prestigious school on the East Coast of the United States. My advanced degrees are all international and therefore seen as superior to the locally sourced varieties. I feel privileged to have had the opportunity to train in this field, however, I have a responsibility to my collective that emerges from my position of privilege in our (post)colonial society. I acknowledge that my parents, grandparents and those long before, had limited access to the education traditions of the culture of power and without their experiences and the resistance and resilience of others of my collective, I would not be where I am today. Transcending the trauma and finding effective coping strategies can take many generations. I am, I think, an example of that persistence, resistance and resilience over multiple generations. I am, I think uniquely qualified to talk about healing and recovery from historical trauma, as the concept pervades every part of my life and is central to my music making and music educating. I would like to describe how I reconcile these two aspects, that is a university lecturer with responsibilities to an academic collective and as a member of an indigenous community with responsibilities to that collective. This position of privilege and power allows me to educate, to activate, to disrupt and to heal my community.

\section{Transforming the culture of power}

Classically trained musicians traditionally prioritize the musical object (Butterfield 2002). The community musician is concerned with the well-being of the person making the music (Higgins 2012, Veblen 2008). While this linkage can seem implausible, community music as a profession increasingly provides income for musicians trained as performers and can become a significant component of a musician's career portfolio. For this reason, my institution like many around the world is creating courses that provide professional development, training and education to performers wishing to become community musicians 
and facilitators. This is not a new connection, it has been a trend since the 1990's (Higgins 2014) when the unlikely "marriage of convenience" (Cole 2011) between institutions of higher education and community music began. While community music can sit "uncomfortably in formal education" (Cole 2011, 79), it provides the opportunity to unpack, reflect and transform a conventional music learning culture and its signature pedagogies.

When working in (post)colonial contexts, the genealogical narrative of a European conservatory model works in direct opposition to the celebration of the local and subdues the counter narrative. In this (s)p(l)ace (de Cosson 2004), we have found it increasingly complicated to create culturally safe and psychologically safe community music sites. To address this issue my colleagues and I have implemented a postgraduate pedagogy course designed to support performance students planning to teach in the community. Originally conceived of as a studio pedagogy course it has over the years included more theoretical discussions around community music facilitation and evolved to include historical trauma as a framework for some modules. This is a deliberate attempt to provide a relevant postcolonial lens to the international and local literature studied throughout the course. The students are directed to scrutinize all course readings and lecture offerings through this lens. They are encouraged to identify the worldview of researcher(s) and the research participants and decide what team they play for. They are asked to consider who will benefit from the outcome of the research. In this way the students begin to regulate the usefulness of the research data by being aware of the cultural and power position(s) of the researcher(s) (Rakena 2016b). The students then apply the same framework to their educational experiences. They reflect on their music making experiences and create narratives, which they share with the class.

One of the objectives of this particular course is to produce future community musicians who think both as music instructors and as critical cultural workers (Freire 1998). By using historical trauma as a framework for analysing community music narratives we can identify practices that enable community educators to better address socio-political issues that are specific to our context. Our goal is to build a set of competencies that will mitigate the influence of cultural narratives that diminish the local and celebrate the culture of power. This brings me to an important story and another disruption.

Te Oti Rakena, Te Oti. 2019. Tears of the collective: Healing historical trauma through community arts. Action, Criticism, and Theory for Music Education 18 (2): 130-46. http://dx. doi.org/10.22176/act18.2.130 


\section{Introducing student $X$ : a performative disruption remixing the meme.}

Student $\mathrm{X}$ was invited to sing in a local proms ${ }^{8}$ concert with a community orchestra. He came to my teaching studio and sang through his selections and then announced that they had also asked him to sing the traditional hymn of the proms, Rule Britannia, at the conclusion of the concert. He didn't know the song but had no problem sight-reading the work. He paused at the end of the read-through and commented, "You know I have a few problems with the words." 9 He paused and considered his options and continued "but I think I know what I will do."

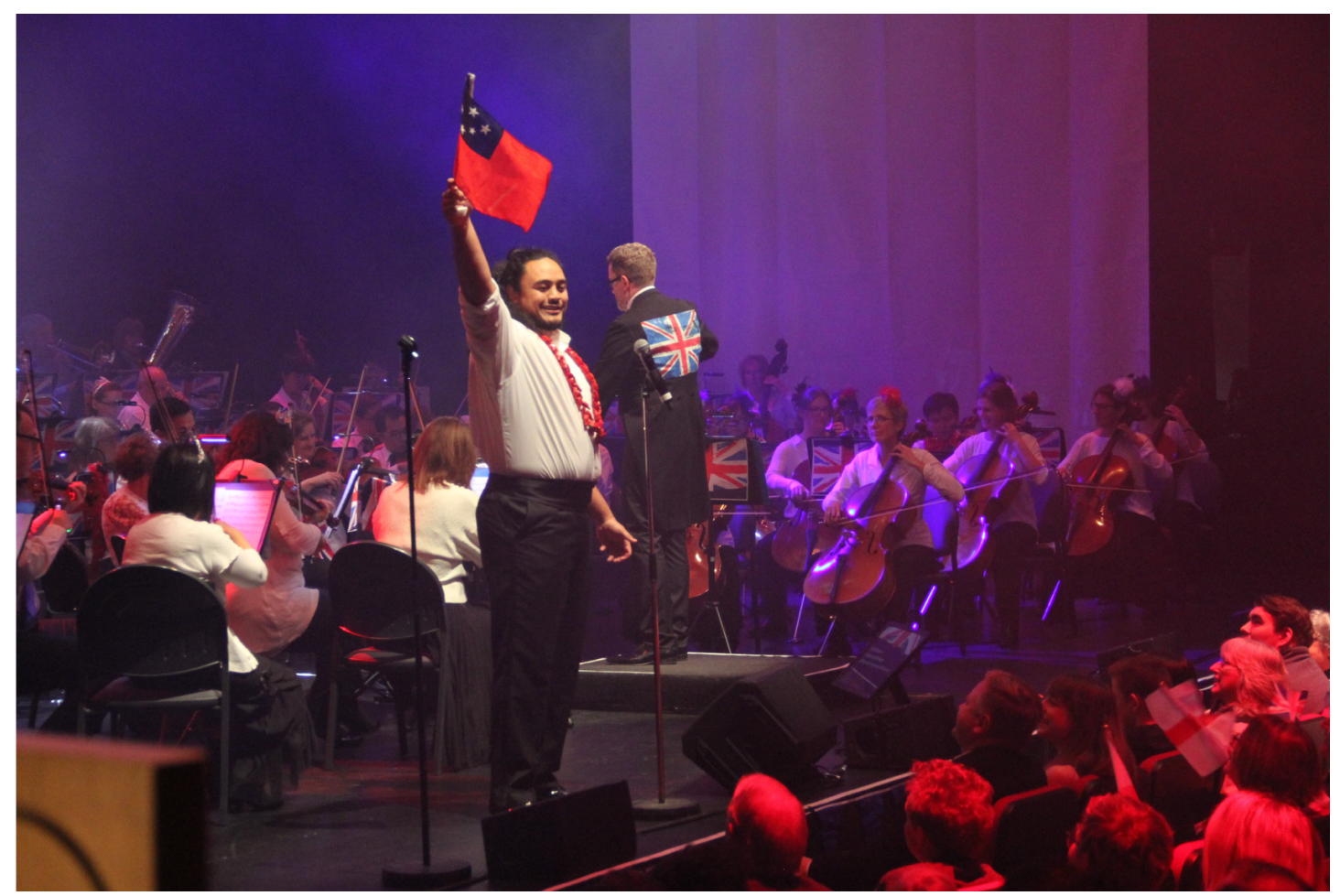

The image above is the result of that brief pause, where he considered how this may impact the people in his community. As you can see while there is a strong representation of union jack flags on the back of music stands and on the back of the conductor (after all, "Britons never, never, never will be slaves"), student $\mathrm{X}$ has taken out a little flag from the Pacific Island nation of Western Samoa. This is a significant remix of a public narrative, which through participatory media became a powerful meme. Snapchat and Facebook uploads of this

Te Oti Rakena, Te Oti. 2019. Tears of the collective: Healing historical trauma through community arts. Action, Criticism, and Theory for Music Education 18 (2): 130-46. http://dx. doi.org/10.22176/act18.2.130 
moment went viral within the Samoan community, a marginalized Pacific Island community in New Zealand, and were picked up by members of the wider musical community. I have extracted the audio from the uploaded video as it provides an interesting counterpoint to the first musical extract and another opportunity to link sound to text. The first example, the Mōteatea, presented a beautifully crafted object that honors and uplifts the culture. When pausing to consider how the extraction of this piece from the larger theatrical work may impact on the people to whom this musical genre belongs, some members of that community may see this as a contemporary exoticizing of the native. The second audio extract presents a different perspective as it backgrounds the musical object and foregrounds the voices of the community. They are responding to a disruption of the performance conventions associated with the musical object Rule Britannia and in so doing their participatory reactions create another representation of community music, similar to the BIARI gallery performance.

\section{[Audio Link]}

Through this teaching-learning process, I have acquired new knowing from student $\mathrm{X}$. He exemplifies a new generation of indigenous performers who are intent on addressing the impact of historical trauma by controlling and transforming their community's public narrative. I take this moment to thank him respectfully for showing me what resilience looks like in this (s)p(l)ace, and for expressing a courage I would never have had at his age. I would have been too fearful of repercussions from the industry and being disrespectful to my friends and colleagues, most of whom belong to the community that descends from the colonial culture. All of this at the expense of an ever widening "soul wound."

\section{The conversation ends...or is it just beginning?}

In this conference, we are eager to disrupt the normal ways we engage with other academics and educators in a conference context. We want to stimulate new knowing, illuminate new perspectives, and inspire non-traditional frameworks for gazing on and participating in community arts education. The conference team acknowledges our location in the South Pacific and our experience as a modern nation state living with a British colonial legacy. Here, there is an uneasy alliance between Western, by this I refer to the Eurocentric framing of 
history and cultural arts and the predominance of Western Philosophy and political theory in shaping the discourse that has become our "truth" (Acharya, Amitav, and Buzan 2010) and non-Western ways that is our "other" truth (Hall 2001). A more trusting relationship seems to be growing between educators from the conservatory traditions and community music educators. Those of ask tasked with preparing performance students to be community educators and facilitators could benefit from this alliance and shift the focus of 2oth century academic framing to a 21st century (s)p(l)ace where we respectfully acknowledge that the educational experts at the community site are perhaps those creative artists who have lived experience and deep content knowledge of the genealogical narratives.

Effective community music educators and facilitators have much to learn from listening and watching indigenous collectives share stories of past trauma. The way they manage grief, the way they transform narratives derived from colonial misrepresentations, and the way they create new historical narratives. All of these musical activities function in a geopolitical space where the dominant culture has contributed to the dilution of the indigenous community's identity, health and well-being. These activities demonstrate how, when deprived of a political voice and effective systemic structures, community music and the other arts can provide a way for communities to lift themselves up, discover new knowing, create viable and culturally safe population health interventions, and inform and transform the culture of power.

\section{About the Author}

Te Oti Rakena is a New Zealand born, American-trained singer. He has a distinguished reputation as a solo performer and academic researcher. Since returning to New Zealand, he has become known for his performances in boutique operas and his commitment to premiering works on themes of national significance. Dr. Rakena has published widely in the area of studio pedagogy, tertiary learning cultures, indigenous methodologies and community music. He is the first indigenous academic to be appointed as a commissioner on the Community Music Activities research commission of the International Music Society of Music Educators.

\section{References}

Acharya, Amitav, and Barry Buzan, eds. 2010. Non-Western international relations theory: perspectives on and beyond Asia. New York: Routledge. 
Atran, Sott. 2001. The trouble with memes. Human Nature 12 (4): 351-81.

Brave Heart, Maria Yellow Horse. 1999. The return to the sacred path: Healing the historical trauma and historical unresolved grief response among the Lakota through a psychoeducational group intervention. Smith College Studies in Social Work 68 (3): 287-305.

Butterfield, Matthew. 2002. The musical object revisited. Music Analysis 21 (3): 327-80.

Cole, Bruce. 2011. "Community music and higher education: A marriage of convenience.” International Journal of Community Music 4 (2): 79-89.

Dawkins, Richard. 1976. The Selfish Gene. Oxford, UK: Oxford University Press.

de Cosson, Alex. 2004. The Hermeneutic Dialogic: Finding Patterns midst the 'Aporia' of the Artist/Researcher/Teacher. (Rewrite \#10 in this context). In $A / r /$ tography. Rendering self through arts based living inquiry edited by Rita L. Irwin and Alex de Cosson, 127-52. Vancouver: Pacific Educational Press.

DeNora, Tia. 2016. Music asylums: wellbeing through music in everyday life. London: Routledge.

Duran, Eduardo, and Bonnie Duran. 1995. Native American postcolonial psychology. Albany, NY: State University of New York Press.

Evans-Campbell, Teresa. 2008. Historical trauma in American Indian/Native Alaska communities: A multilevel framework for exploring impacts on individuals, families, and communities. Journal of Interpersonal Violence 23 (3): 316-38.

Foucault, Michel. 1984. The order of discourse. In Language and politics edited by Michael Shapiro, 108-38. New York: New York University Press.

Freire, Paolo. 1998. Teachers as cultural workers: Letters to those who dare to teach, translated by Donaldo Macedo, Dale Koike, \& Alexandre Oliveira, Trans. Boulder: Westview Press.

Hall, Stuart. 2001. The West and the Rest. In Formations of Modernity edited by Stuart Hall and Bram Gieben, 257-330. Milton Keynes: Open University Press and Blackwell.

Higgins, Lee. 2012. Community music: In theory and in practice. New York: Oxford University Press.

Te Oti Rakena, Te Oti. 2019. Tears of the collective: Healing historical trauma through community arts. Action, Criticism, and Theory for Music Education 18 (2): 130-46. http://dx. doi.org/10.22176/act18.2.130 
Hinyard, Leslie, and Matthew Kreuter. 2007. Using narrative communication as a tool for health behavior change: a conceptual, theoretical, and empirical overview. Health Education \& Behavior 34 (5): 777-92.

Kirmayer, Laurence, Joseph Gone, and Joshua Moses. 2014. Rethinking historical trauma. Transcultural Psychiatry 51 (3): 299-319.

Meštrović, Stjepan. 1985. A sociological conceptualization of trauma. Social Science \& Medicine 21 (8): 835-48.

Milner, Ryan. 2012. The world made meme: Discourse and identity in participatory media. PhD diss., University of Kansas.

Mohatt, Nathaniel, Azure Thompson, Nghi Thai, and Jacob Tebes. 2014. Historical trauma as public narrative: A conceptual review of how history impacts present-day health. Social Science \& Medicine 106: 128-36.

Pihama, Leonie, Paul Reynolds, Cherryl Smith, John Reid, Linda Tuhiwai Smith, and Rihi Te Nana. 2014. Positioning historical trauma theory within Aotearoa New Zealand. AlterNative: An International Journal of Indigenous Peoples 10 (3): 248-62.

Panelli Ruth, and Gail Tipa. 2007. Placing well-being: a Maori case study of cultural and environmental specificity. EcoHealth 4 (4): 445-6o.

Rakena, Te Oti. 2016a. Sustaining indigenous performing arts: Te potential decolonizing role of arts-based service learning. In Engaging first peoples in arts-based service learning: Towards respectful and mutually beneficial educational practices, edited by Brydie Leigh Bartleet, Dawn Bennett, Anne Power, and Naomi Sunderland, 119-31: Switzerland: Springer.

Rakena, Te Oti. 2016b. Forging genuine partnerships in the music studio context: Reviving the master-apprentice model for post-colonial times. In Intersecting cultures in music and dance education: An Oceanic perspective edited by Linda Ashley and David Lines, 119-33. Switzerland: Springer.

Riessman, Catherine. 1993. Narrative analysis. Newbury Park CA: Sage Publications.

Sheffield, Carrie Louise. 2011. Native American hip-hop and historical trauma: Surviving and healing trauma on the "Rez". Studies in American Indian Literatures 23 (3): 94-110.

Smith, Linda Tuhiwai. 1999. Decolonising methodologies: Research and indigenous peoples. London: Zed Books. 
Smith, Valance. 2003. Colonising the stage: The socio-cultural impact of colonisation on Kapa Haka. Unpublished masters' thesis, University of Auckland, New Zealand.

Veblen, Kari K. 2008. The many ways of community music. International Journal of Community Music 1 (1): 5-21.

Wirihana, Rebecca, and Cheryl Smith. 2014. Historical trauma, healing and well-being in Maori communities. Mai Journal 3 (3): 197-210.

Young, Allan. 1997. The harmony of illusions: Inventing post-traumatic stress disorder. Princeton: Princeton University Press.

Ministry of Justice (n.d.) Treaty of Waitangi. Accessed May 3, 2018. https://www.justice.govt.nz/about/learn-about-the-justice-system/howthe-justice-system-works/the-basis-for-all-law/treaty-of-waitangi/

\section{Notes}

${ }^{1}$ Tauparapara is a blessing or a type of chant that begins a speech. In this case it replaces the term introduction, as this does not capture the significance of this narrative which should be imagined as intoned on one pitch with rhythmic freedom.

2 Tānenuiarangi is an important god in Oceanic and Māori mythology. He ascended to the highest realms of heaven and brought back three baskets of knowledge. With that knowledge he created humankind and gave them knowledge of things earthly and spiritual.

3 The master carver Pākariki Harrison (Paki) conceived and designed the meeting house at the University of Auckland's marae.

4 Māori was a word originally used to mean normal or ordinary, but after contact with Europeans this became the usual term to differentiate people of indigenous New Zealand descent from people descended from other settler and immigrant nations.

5 Aotearoa was originally the name for the North Island of New Zealand but has become the most common Māori word used to translate New Zealand.

${ }^{6}$ Tangi'ia is an Oceanic God of particularly importance in some migration stories.

7 This word means people, and the repeating of it three times signals a connection to a well-known Māori proverb that translated asks; What is the most important thing in the world? It is people, it is people, it is people. 
8 This refers to a British cultural event that has occurred at the Royal Albert Hall in London since 1895. Of significant importance is the last night of the proms, a moment that is still reproduced in some colonial outposts of the world and ends with the singing of the patriotic song Rule Britannia.

9 The original text of the song, words by James Thomson and set to music by Thomas Arne in 1740, includes the rousing patriotic chorus "Rule, Britannia! Britannia, rule the waves! Britons never, never, never shall be slaves."

Te Oti Rakena, Te Oti. 2019. Tears of the collective: Healing historical trauma through community arts. Action, Criticism, and Theory for Music Education 18 (2): 130-46. http://dx. doi.org/10.22176/act18.2.130 